\title{
Developing Modelling-Based Speaking Module for Informal Interaction to Support Independent Learning of Speaking Skill
}

\author{
Ratih Laily Nurjanah ${ }^{1}$, Deswandito Dwi Saptanto ${ }^{2}$, Maya Kurnia Dewi ${ }^{3}$ \\ ${ }^{1}$ Universitas Ngudi Waluyo, Jawa Tengah, Indonesia \\ email: ratih.laily@gmail.com \\ ${ }^{2}$ Universitas Ngudi Waluyo, Jawa Tengah, Indonesia \\ email: dittoissublime@gmail.com \\ ${ }^{3}$ Universitas Ngudi Waluyo, Jawa Tengah, Indonesia \\ email: sachi.mai@gmail.com
}

\begin{abstract}
The lack of English module in speaking skill to support the teaching and learning process becomes one of the reasons for this study to come up. Another one is the reality that now, students are expected to be able to develop themselves independently without being dependent on lecturers since the Ministry of Education issued a new curriculum of Kampus Merdeka (Independent Campus). This is such an extended period from what is being faced by the world during outbreak era where classroom activities cannot be held. This study aims to observe what kind of speaking module is needed by students and to develop a modelling-based speaking module in informal interaction to support the independent learning process. This is a research and Development method according to Borg and Gall theory with 10 steps of development. The results show students need a module that can give them examples how to pronounce words but not in form of phonetic transcription. A module is then developed containing various daily expressions accompanied by an USB flash-drive contains recordings of a native speaker giving examples or models on how to pronounce the expressions accurately. Student are expected to be able to imitate the examples whenever they need until they can produce correct pronunciation and intonation.
\end{abstract}

Keywords: Teaching speaking, Speaking Module, Independent Learning, Modelling-based

\section{INTRODUCTION}

In order to adapt to modernization in nowadays, the improvement of English competency is instilled from an early age to the university level. According to (Kurniasih, 2011), the first thing we have to do is prepare students as early as possible to learn foreign languages. Second, the educators must introduce how important it is to master foreign languages in life, especially to get a job. Third, the educators and students must be able to work ELT- Lectura, Vol 8, No 1, February 2021 together in using language and students must become central learning in the activities, while education is as a mediator for these learning and teaching activities. At the university level, the students are the main key to answering all concerns about the lack of competence of the Indonesian people in the realm of mastering English.

Mastering English in the university students begins with the mastery of the use of English in an informal context (daily 
conversation) as a starting point before moving to a higher level. The existence of Basic English learning concepts begins with prioritizing the mastery of speaking competence as a form of orally and actively. In order to support the mastery of speaking in English, the learning process is emphasized more on the scope of improving speaking competence, supported by more applicable and varied learning materials.

The current problem is the lack of modules or supporting media for learning in the classroom that can help students practice speaking skills in real terms. In the early stages of learning, it is very important to provide the correct example or model to students as a basis for learning and the use of subsequent concepts. Most of the speaking learning modules currently only provide a list of expressions whose pronunciation is exemplified by the lecturer in the classroom and the rest of the students are expected to be able to learn and practice on their own. In learning and improving English skills in the realm of speaking, the students must practice directly and meet many friends to talk. This is the most basic concept in improving speaking skills in English. As proposed by (Burns, 2017), speaking English involves combination of various skills, knowledge, and processes that take account of the contexts of production, and result in speech that is culturally and socially relevant, appropriate, and comprehensible to their interlocutors, as well as managing microlevel reactions and responses to what they utter. This shows that teaching speaking in English is more than just involving students in conversation. It should start from giving them proper knowledge about how to and what to speak.

The problem with the lack of modules or supporting media is also followed by a lack of models or examples in the learning itself. The lecturers as examples in class sometimes also have limitations in their speaking skills. The development of this modeling-based speaking module provides a new learning medium for students in the classroom.

\section{|ELT-Lectura: Studies and Perspectives in English Language Teaching}

Copyright $\odot 2021$ Ratih Laily Nurjanah, Deswandito Dwi Saptanto, Maya Kurnia Dewi
While students still need some models, the condition nowadays where students and teachers are forced to do distant-learning, it is quite difficult for students to be in a controlled situation where they can practice their speaking skill. Moreover; the Indonesia government proposes a new curriculum for universities where students are demanded to spend more time outside campus for self-development programs instead of spending time in classroom teaching and learning with lecturers. This condition also becomes a problem where students can be lack of guidance to practice either they do not have models or they do not know what to do because there is no structured activities given.

By evaluating the conditions, the research problems are proposed to solve them by observing and evaluating the needs of students of speaking module. Hence; this study aims to find out what kind of speaking module is needed by students and to develop a modelling-based speaking module in informal interaction to support the independent learning process.

State of the art or novelty in this research is the provision or development of a learning medium that supports the independent learning process in the distance learning period where students learn without direct assistance from the teacher or lecturer. In a previous study conducted by (Malihah, n.d.), speaking was taught by using techniques and task-based learning methods which were carried out by giving students tasks to improve their speaking skills. In this case, the technique can be implemented for students who have passed the initial level. For students at the beginner level, the imitation/ modeling method is considered very appropriate to give students the right habituation in pronouncing English. Correct pronunciation is one of the basics of mastering English, especially speaking skills. Thus, giving examples that are deemed appropriate are examples spoken by native speakers themselves. As the novelty of this study, it provides a module for teaching speaking based on modelling technique can be used independently by students because the module is accompanied by a CD containing models or 
examples from native speaker. The inclusion of a CD containing recorded examples of pronunciation by native speakers is one of the media that supports the self-learning process that can be applied in the current distance learning period. This module is expected to give contribution to the teaching of speaking skill during online learning where teachers and students may be impossible to meet face-to-face by giving possibility for students to be guided and get proper examples.

A communicative and interactive approach to learning English is needed by every student in higher education to achieve the expected output results. The mentoring process and material in accordance with the competencies that are expected to play a major role in learning activities. The most important thing in learning English is the availability of sufficient time to carry out direct presentation practice. As stated by (Aljoundi, 2016) that the way to acquire a language is by learn to speak and write meaning that speaking ability plays an important role in the basic concepts of learning English. Referring to its function, the English language media as a means of communicating both internally and externally is essential in everyday life.

According to (Widiati, n.d.), the spoken English in Indonesia this last few years has implemented the concept of Communicative Language Teaching (CLT) approach referring to the interactions among students in the process of language learning based on communicative competence to improve the speaking proficiency. From this, we can argue that the target of learning speaking in English is to maintain a communication or interaction which is surprisingly still becomes a difficulty for students of university level though in Indonesia, English is taught starting from secondary level.

The students in Indonesia may face same problems as those in other countries learning English as a foreign language. (Bouzar, 2019) proposed that learning spoken grammar forms and apply in faceto-face talk is important to make students aware of spoken grammar features through some activities given in the classroom. He called it "consciousness-raising" which involves isolating specific linguistic features, explicit rule description, using intellectual effort to understand and articulating the rules describing the grammatical feature. In short, in consciousness-raising, learners are required to pay attention, to notice and to understand certain features of language though they do not need to produce or communicate certain pattern taught.

While (Burns, 2019) argued that the process of teaching speaking itself involves understanding the 'combinatorial' nature of speaking including the linguistic and discoursal features of speech, the core speaking skills so that speakers are able to process and produce speech, and the communication strategies for managing and maintaining spoken interactions. This argument is related to the use of expressions in English in communication. The expressions in English such as "How are you?" or "How do you do?" or expressions of asking and giving opinion help them to produce and maintain conversation in real life without applying certain grammatical patterns as in written language.

Learning foreign languages for students at the university level is the main thing to be able to understand the relationship between languages and cultures of other nations as a form of broadening the horizons of knowledge. The process of learning English in university levels certainly refers to the established English learning curriculum. 
The students, as individuals, must be prepared by the lecturers as their teachers to be able to develop their personality, knowledge and skills as well as live in a community. Proficient competence in using English is a real form of expertise and skills that must be mastered by every student in higher education.

Lately, higher education is lead to the implementation of Independent-Campus Curiculum where students are expected to be able to learn even without having faceto-face learning session with lecturers in the classroom. This causes another habit or culture that should have been shaped from now.

The culture of independent learning should be an alternative to make students learn independently. This skill is also known as Self-Regulated Learning and have been applied in various skills teaching.

Nurjanah (2020) in the study applied the method in teaching reading where students have to be able to monitor their own development in reading comprehension skill by involving them in structured activities based on structured instructions in a handout.

Bloom (2013) stated that the implementation of this method of learning involves goal setting, self-efficacy and motivation. The module or handout or learning activities gives to students must be based on these aspects to make the method effective.

\section{Speaking Ability}

The quality of speaking English in a person depends on the quantity and quality of vocabulary they have, the more vocabulary we have the more likely we are to become skilled at language.

\section{Stages of Speaking}

|ELT-Lectura: Studies and Perspectives in English Language Teaching Copyright@ 2021 Ratih Laily Nurjanah, Deswandito Dwi Saptanto, Maya Kurnia Dewi
Communication using a foreign language, in this case English, has its own challenges. This is because language is a symbol system that is understood by each other so that an understanding is created in communication. Concluded from (Gilakjani \& Ahmadi, 2011), the stages of speaking include:

a. Passive speaking, at this stage, someone listens more to the various forms and styles of speaking of others, speech, language structures used, and vocabulary development. A person in this phase is just learning to apply English passively because he is still in the process of learning new words or basic sentences.

b. Active Speaking, a person is more able to practice speaking directly in English so that a person not only has the ability passively, but also able to practice directly actively. Someone at this stage is able to ask, explain and give statements to others.

c. Two-ways Speaking, the mastery of the ability to speak using English fluently between the two parties so that active communication is formed. At this stage a person has mastered the competence of using simple sentences, multi-tiered compound sentences to complex sentences.

\section{Speaking Module and Modelling Technique}

Learning guidance in the form of modules that are often used in learning has contributed greatly in helping someone have skills in mastering English. The concept of the method of imitating the audio sound from a native speaker with the name shadowing Tape or $\mathrm{CD}$ has been proven to be successful in improving the quality of students' understanding and competence as can be concluded from 
(Klancar - Developing Speaking Skills in the Young Learners Classroom (TESL_TEFL), n.d.) who argues;

Combining the approaches, varying the cognitive styles, mixing and matching various methods and tools - e.g. songs, games, chants, rhymes, dialogues, etc. provide the students with maximum variety and (in turn) offers them plenty of opportunities to play an active part in communicative situations, ranging from simple imitation to conscious exchange and internalization of certain vocabulary items / pronunciation styles / grammatical points / communicative techniques, at the same time building strategies that will help them later on when their knowledge of English has advanced and moved to a higher level.

The use of varied learning support media makes a big contribution to one's success in the English learning process. One of them is through a module which is accompanied by an audio CD from a native speaker. This concept can simplify the process of imitating pronunciation including articulation, pronunciation, and intonation for someone who is studying English.

In their study, (Hartatik, 2016), used authentic materials from videos or movies to teach speaking. This can be an alternative way but students found out that when it came into question whether the AMs were comprehensible or not, students thought that authentic materials, especially in spoken one, were not easy to understand. This is such a perfect way of teaching when students are considered familiar enough with basic expressions involved in daily conversation. This can motivate students to learn more English vocabulary or use English in conversation but still it is not proper enough to accommodate students' needs of examples and proper introduction to speaking activities.
According to (Sutarsyah, 2017) in the study, The data show that speaking anxiety may give negative contribution to the overall students' speaking performance achievement. It also found that nervousness is dominant factor followed by worry and tension. The anxiety may be caused by students' limited knowledge on what they have to say in certain situation. This shows that students should be given proper knowledge on the basic speaking skill, this can also be caused by being afraid of making any errors or mistakes.

From this, a module that can help students in understanding daily expressions and help them practice independently is proposed. This module applies the principle of teaching speaking from formulaic competence which was proposed by (Pakula, 2019) that the pedagogical implication in spoken English is related to the teaching of formulaic expressions/ sequences, the teaching of spoken grammar, the teaching of linguistic, sociolinguistic and pragmatic competences. Formulaic expressions here is defined by Alwhan (Info, 2019) as something like collocated words that are formed by speakers to serve different functions like: introducing a subject, identifying the speaker and structuring turn-taking. The use of the formulaic expressions is somewhat different from other formulas. The former emphasizes the functions while the latter emphasizes the meaning. The structure of formulaic expressions sometimes does not follow the certain grammatical rule or seem meaningless such as "How do you do?" but this functions as one of opening in conversations to ask about how the partner feels. The use of formulaic expressions can be an indicator of students' fluency since the use of it involves students' competence in comprehending sociolinguistics (understanding social condition), pragmatics, and socio-culture.

|ELT-Lectura: Studies and Perspectives in English Language Teaching Copyright $@ 2021$ Ratih Laily Nurjanah, Deswandito Dwi Saptanto, Maya Kurnia Dewi 
The modelling technique implemented in this module is based on (Salisu \& Ransom, 2014) who stated that modelling skill is useful not only for children but also adults by playing important role in acquisition and development of cognitive and metacognitive skills, fine motor skills, interpersonal skills, and later professional skills. By using modelling as type of instruction, lecturers can involve students in imitating certain behavior that encourages learning process. There are some types of modelling proposed; 1) disposition modelling; it works by giving model to students in terms of personal character such as integrity, empathy, 2) task and performance modelling; it works by giving example to students on how a task be done such as in experiments, foreign language communication, physical education tasks, 3) meta-cognitive modelling; it works by demonstrating students about how to think, such as in making conclusion.

By implementing the modelling technique, it means that teacher should consider students' learning process by giving them examples before ask them to perform the task by themselves. This becomes the foundation on giving students structured-activities to be done to improve their language skill.

Since students still need model to even pronounce the words or expressions, this module comes up with audio files to be models for students to practice, enrichment related to formulaic expressions, and structured activities can be used by students either under lecturer's instructions or independently.

Provide an adequate review of literature. The section headings are arranged by Numbers, bold and $12 \mathrm{pt}$ Times New Roman, single spacing. Paragraphs shall be single-spaced with no indent. Provide an adequate review of literature. The section headings are arranged by
Numbers, bold and 12 pt Times New Roman, single spacing. Paragraphs shall be singlespaced with no indent.

Provide an adequate review of literature. The section headings are arranged by Numbers, bold and 12 pt Times New Roman, single spacing. Paragraphs shall be single-spaced with no indent. Provide an adequate review of literature. The section headings are arranged by Numbers, bold and 12 pt Times New Roman, single spacing. Paragraphs shall be singlespaced with no indent.

\section{METHOD}

The Research Methods section describes in detail how the study was conducted. A complete description of the methods used enables the reader to evaluate the appropriateness of the research methodology.

\section{Research Design}

This research applied Research and Development Method by Borg and Gall.

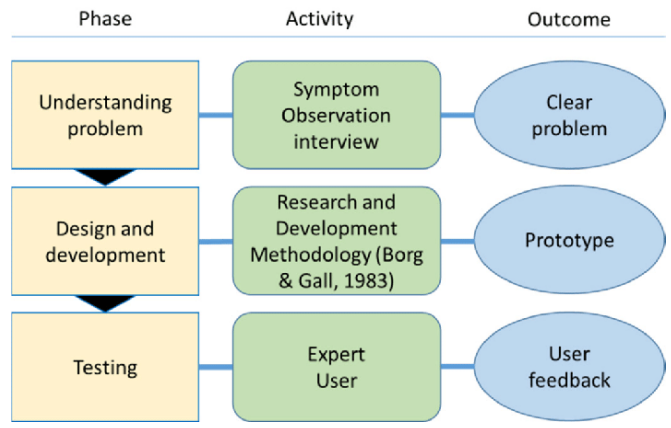

The first phase is understanding problem to observe the gap or problems found by examining symptoms, observing, and interviewing. This phase results clear problem to be discussed. (Dalle \& Mangkurat, 2018). The second phase is design and development by implementing the research and development method by Borg and Gall. This phase results a prototype. The last phase is testing involving expert users to get feedback from users. 
The research and development method by Borg and Gall can be described in following diagram (Yanti et al., n.d.)

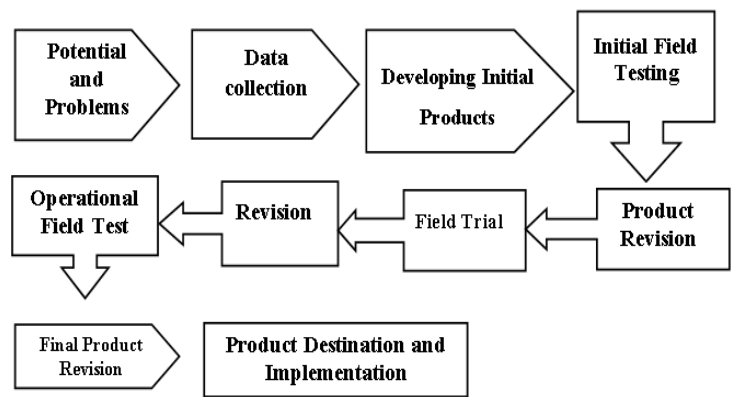

Figure 2. Borg and Gall R\&D Diagram

This research stopped at the final product revision because product destination and implementation are considered requiring longer period of production.

\subsection{Participants}

The subjects were about 40 students of basic speaking-classes. The reason for having them is because the module contains daily expressions and is intended to give examples so the basic-level students were considered as the best subjects for the research.

The Research Methodology section describes in detail how the study was conducted. A complete description of the methods used enables the reader to evaluate the appropriateness of the research methodology.

\subsection{Instruments}

The instruments used in this study are questionnaires distributed before and after development to find out students' needs and their perspectives about the product.
Table 1.

Pre-Design Questionnaire

\begin{tabular}{|c|c|c|}
\hline No. & Question & Answer \\
\hline 1. & $\begin{array}{l}\text { What are the difficulties } \\
\text { you face during online } \\
\text { learning? }\end{array}$ & \\
\hline 2. & $\begin{array}{l}\text { Do you think speaking- } \\
\text { class activities can be } \\
\text { done through online } \\
\text { classroom? }\end{array}$ & \\
\hline 3. & $\begin{array}{l}\text { Do you find the module } \\
\text { used by lecturer until } \\
\text { now is helpful? What } \\
\text { makes it so or not? }\end{array}$ & \\
\hline 4. & $\begin{array}{c}\text { What kind of module do } \\
\text { you think you need } \\
\text { during online-speaking- } \\
\text { class? }\end{array}$ & \\
\hline 5. & $\begin{array}{l}\text { What do you think you } \\
\text { need the most from this } \\
\text { beginning level of } \\
\text { speaking class? }\end{array}$ & \\
\hline
\end{tabular}

Table 2.

Final Revision Questionnaire

\begin{tabular}{cc}
\hline No. & Question \\
\hline 1. & $\begin{array}{c}\text { What are the advantages } \\
\text { of using the module? }\end{array}$ \\
\hline 2. & $\begin{array}{c}\text { What are the difficulties } \\
\text { in using the module? }\end{array}$ \\
\hline 3. & $\begin{array}{c}\text { What shold be included } \\
\text { to the module for further } \\
\text { development? }\end{array}$ \\
\hline
\end{tabular}




\section{FINDINGS AND DISCUSSION Potential and Problems}

The potential problems were observed from the daily phenomenon of teaching speaking to the $1^{\text {st }}$ semester students of English Literature Department at Universitas Ngudi Waluyo. Many of students are not fluent enough to pronounce nor use the common daily expressions. Moreover, the COVID-19 outbreak forces the teaching-learning process to be held through internet. This fact creates another problem that not many students live with stable internet connection so it was quite difficult to have video-conference call. The lack of module to support students to learn and practice their speaking skill independently. This independence is also required later when Kurikulum Kampus Merdeka (Independent Campus Curriculum) is applied where lecturers and students are allowed to not have meetings in the classroom. The existed module is considered not supporting the online learning process.

\section{Data Collection}

The data collection was done by distributing questionnaire to the Universitas Ngudi Waluyo students in speaking for informal/basic speaking class as subjects to see the difficulties they face related to online learning and what they needed to support the learning especially, the independent one. The questions were designed with open-ended questions to get accurate answers.

From the questionnaire distributed, it can be concluded that while speaking skill needs to be practiced under guidance from lecturer, the signal to have conference call or send students' works in forms of videos or recorded audio may be limited. The module used by lecturer so far is not really helpful while being used independently by students especially during distant-learning.
Students need a module or a guide book that they can use without depending on their lecturers. Since they are in the beginning level, they are still afraid of making mistakes or errors and need clear examples from lecturers or trusted sources.

\section{Developing Initial Products}

The initial product was designed based on the course description, objectives, and questionnaire results. First, the expressions were categorized into the functions. For example, below is the content of unit 1 , describing the objectives of learning in the beginning and providing a dialogue as example of how expressions are used completed with dictionary explaining certain phrasal verbs.

Figure 4. Unit 1 Modelling-Based Speaking Module

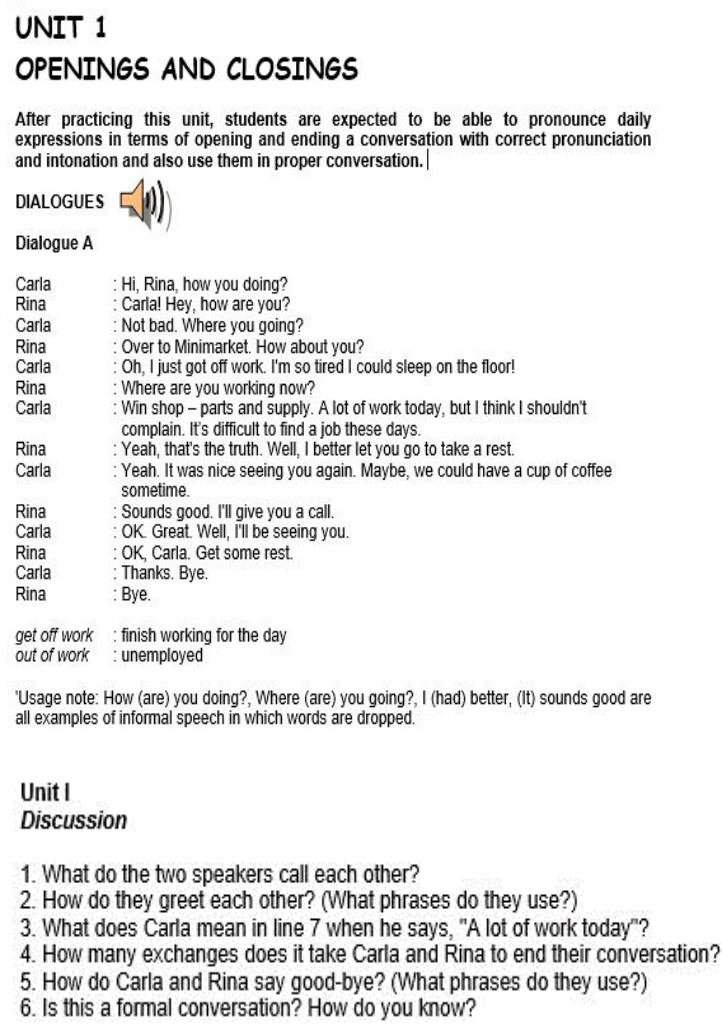

'Usage note: How (are) you doing?, Where (are) you going?, I (had) better, (It) sounds good are all examples of informal speech in which words are dropped

Unit I

Discussion

1. What do the two speakers call each other?

2. How do they greet each other? (What phrases do they use?)

3. What does Carla mean in line 7 when he says, "A lot of work today"?

4. How many exchanges does it take Carla and Rina to end their conversation?

5. How do Carla and Rina say good-bye? (What phrases do they use?)

6 . Is this a formal conversation? How do you know?

The discussion part was provided to help students comprehend the conversation based on the context. 


\section{Initial Field Testing}

After being produced 3 units consisting of Openings and Closings, Introducing Self, and Controlling Conversation, the module was then tested. The subjects of the test were 40 students participating in initial survey. After being tested by implementing the module in learning process, students revealed that it was better if the activities given related to the topic were included to the module so students know what to do with the book besides reading a dialogue and practicing it. Researchers then decided to revise the module based on students' suggestions.

\section{Product Revision}

Based on previous step, the module was then revised by adding more dialogues to practice, more enrichment such as phrases to use, and structured activities to give students more-organized learning activities.

Figure 5. Enrichment Materials

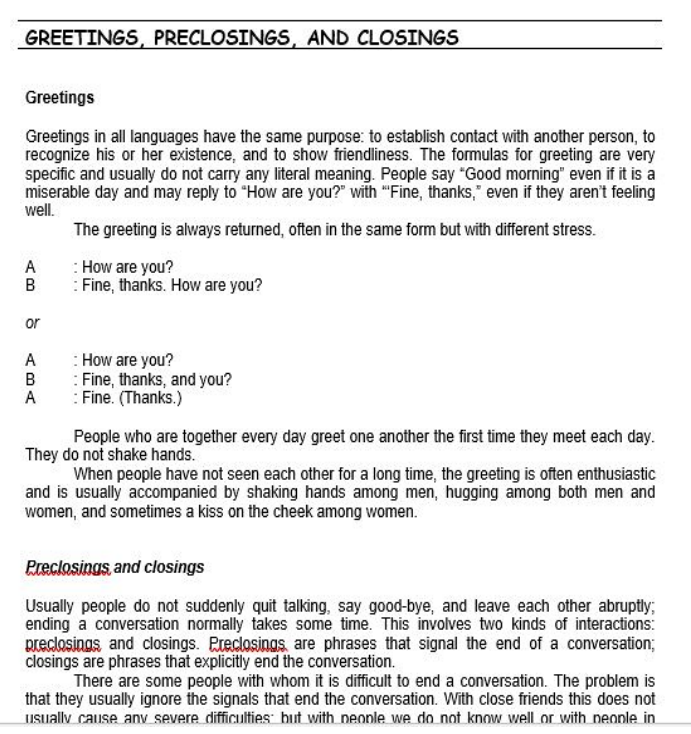

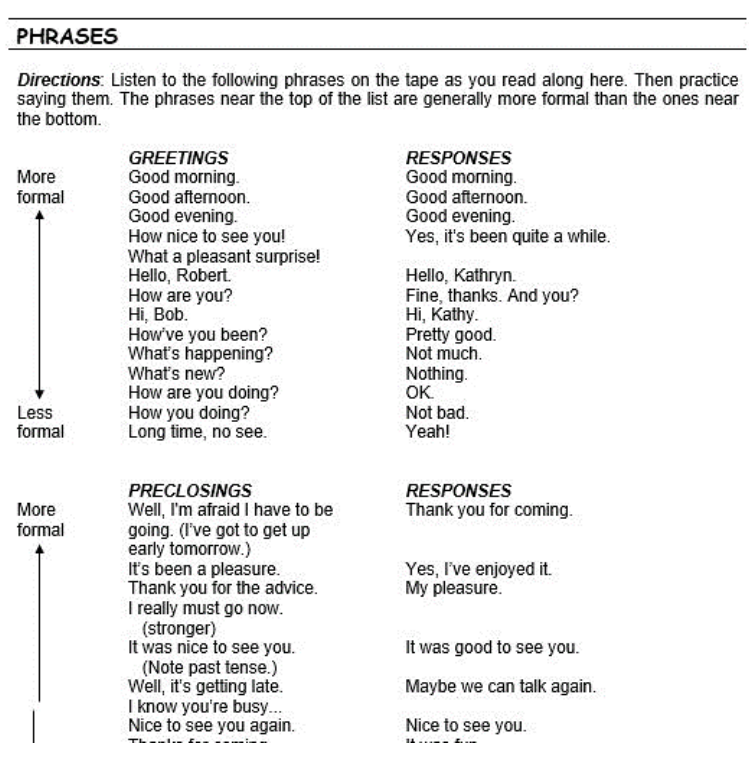

Figure 6. Structured Activities

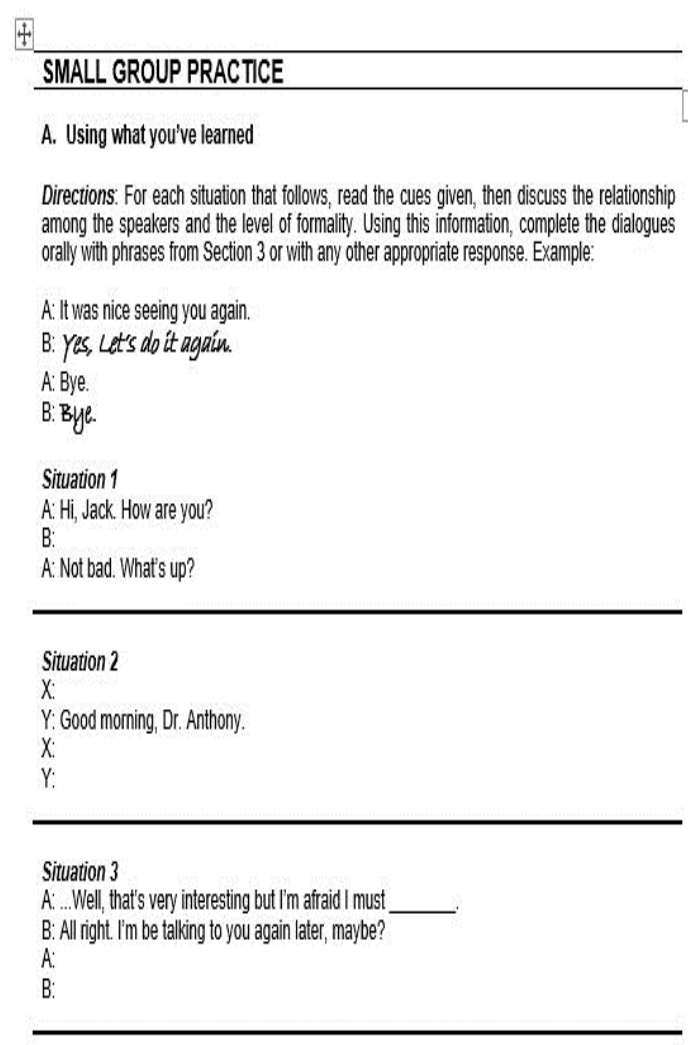

\section{Field Trial}

The field trial was given to 70 students; 40 students were those participating in survey and other 30

|ELT-Lectura: Studies and Perspectives in English Language Teaching

Copyright@ 2021 Ratih Laily Nurjanah, Deswandito Dwi Saptanto, Maya Kurnia Dewi 
students were $1^{\text {st }}$ semester students from other private university in Semarang city. Another finding came up during this trial. Students felt that there was a need of getting examples or models on how to pronounce the expressions correctly with accurate intonation. Based on this finding, a further revision was planned.

\section{Revision}

To accommodate the needs of getting examples or models, audio CD to complete the module was planned. Since students need standardized model of pronunciation and intonation, a native English speaker was involved in this research as a voicetalent to give examples on how to pronounce every expression and phrase in the module.

\section{Operational Field Test}

The operational field test was done to 70 students. During this trial, students revealed that most of them did not have any $\mathrm{CD}$ players to play the $\mathrm{CD}$. The materials helped them a lot during the application. Revision was needed to overcome the difficulty.

\section{Final Product Revision}

As a solution to the problem occurred, a USB flash-drive was chosen to replace audio $C D$. USB flash-drive was considered practical and efficient to be used by students since all of them have laptop to work with. A USB flash-drive can also work with other players.

After the final product revision, the module was then showed to students to be reviewed along with the USB flash-drive. A questionnaire was distributed.

From the questionnaire, it can be concluded that the module was considered helpful by students since it enables students to learn without needing much signal or data.
There were not any difficulties found by students while using the module independently.

\section{Discussion}

The result of this research is a modelling-based speaking module of informal interaction accompanied by a USB flash-drive containing audio file giving examples on daily expressions' pronunciation by a native English speaker.

This module contains of 5 units; Closings and Openings, Introducing Self, Controlling Conversations, Asking and Giving Opinions, and Getting Direction.

Each unit consists of 3 samples of dialogue with a discussion session in each, enrichment materials of explanation and phrases, and structured activities such as, role play scenarios within small groups or in pairs.

One of the easiest steps to learn language is imitating. Beginner learners of foreign language are given examples or models as they later are expected to be able to imitate. This imitation is expected to make them used to correct pronunciation or intonation.

The models of pronunciation given by native English speaker in the module are aimed to help students learn the expressions in correct ways.

Besides the examples of dialogue, materials enrichment of explanation and phrases are aimed to give students more knowledge about vocabulary related to the topic or daily expressions.

Structured activities stated in the module so students can prepare their own activity before getting into the lesson. This step is offered to reduce the anxiety of students from getting sudden tasks from lecturers. 
The development of this module is based on the idea stated in previous study that a course design should start from assumptions forming the purposes and subsequent course development and that learning process must be put in sequence orders to help students relate the materials with their prior-knowledge supported by activities working on both passive and active activities. Those activities can be guided by various resources to help students learn deeply and experience course-centered learning. The resources are expected to be in multimodal to adjust with students' interests, comprehension, competencies, and it should be consistent with the content and access to technology. (Piña, n.d.) From this previous study, it can be seen that the module developed in this study has met the standards in which it is multimodal, by providing text an audio, it involves new resources by involving native speakers as the model, and it is coursecentered by involving students in speaking activities starts from giving examples before finally asking students to create their own dialogues. The module also states clear learning objectives in each of the units.

In other previous study related to online learning, it is stated that the implementation of learning activities online should involve lecturers or instructors' roles to prevent students from getting false information or resources for their learning activities. Students should still be motivated to search help from classmates or lecturers instead of depending on online resources only (Wandler \& Imbriale, 2017). This module is also aligned with that statement by giving opportunity to students to communicate with the lecturers and get feedback related to their performance. This supports the idea that online sources should not be the only sources used by students. They still need guidance from their lecturers to keep the activities on track.
The other previous study showed that students need to build their own argument related to learning activities. (Overdijk, 2009) From this statement, this module is then developed by enabling students to use the module independently. The instructions and activities were stated clearly and the examples are also given in audio file so students can learn anytime they want. It is expected to help students build an opinion that learning can be done independently while they still can ask feedback or seek help from the lecturers.

A previous study also revealed that it is important for teachers to consider the anxiety levels of students and prepare strategy to solve it (Abdurahman et al., n.d.). By using this module independently, it prevents students from getting anxiety since they can practice based on the models or examples given as many as they want. They will be prepared better so they can perform better results in speaking skill.

Another study related to technology usage in learning showed that digital tools, like the internet, podcasts, are regarded as ways of assisting students enhance their language skills (Bahadorfar \& Omidvar, 2014). Involving the audio files in the module as one of learning media reflects the findings of this previous study so students are getting more interested in learning using the module.

\section{CONCLUSION}

To this point, I have presented what students need in speaking class during the online learning period and how a module with models from native English speaker was developed. Students feel they need to get clear overview on what activities they need to do in speaking class especially when the class is held online. The module developed in this research is considered to 
be helpful by accommodating students' needs based on every trial.

This module can help students learn independently because they can check the examples from USB flash-drive whenever they need. They also do not need to be hesitate to ask for repetition since they are in control of the USB. Students can learn by imitating the recording as many as they want. By having this learning media, lecturer's role is limited to give instructions and overview of the unit, assess and give feedback to students about their performances when needed.

The research, is therefore significant because this kind of module, which supports and helps students learn independently can be implemented to support the learning process under Independence Campus Curriculum.

\section{REFERENCES}

Abdurahman, N. H., Rizqi, A., Prof, J., Nawawi, H. H., Tenggara, P., Laut, B., \& Kalimantan, W. (n.d.). INDONESIAN STUDENTS STRATEGIES TO COPE Universitas Pendidikan Indonesia. 1-18.

Aljoundi, E. K. (2016). language acquisition theories. May 2014. https://doi.org/10.13140/RG.2.1.1381. 1607

Bahadorfar, M., \& Omidvar, R. (2014). Technology in teaching speaking skill. 9-13.

Bloom, M. (2013). Self-regulated learning: Goal setting and self-monitoring. The Language Teacher, 37(4), 46. https://doi.org/10.37546/jalttlt37.4-6

Bouzar, S. (2019). Issues in Teaching Speaking to EFL Learners. 5(1), 7079.

https://doi.org/10.5296/elr.v5i1.14705
Burns, A. (2017). in the Second Language Classroom. May.

Burns, A. (2019). Concepts for Teaching Speaking in the English Language Classroom 1. 12(1), 1-11.

Dalle, J., \& Mangkurat, U. L. (2018). Interactive courseware for supporting learners competency in practical skills Interactive Courseware for Supporting Learners Competency in Practical Skills. July 2017.

Gilakjani, A. P., \& Ahmadi, M. R. (2011). A Study of Factors Affecting EFL Learners , English Listening Comprehension and the Strategies for Improvement. 2(5), 977-988. https://doi.org/10.4304/jltr.2.5.977-988

Hartatik, S. F. (2016). Investigating the Students' Views on the Authentic Materials Used in Basic Speaking Class. 1(1), 1-10.

Info, A. (2019). An Overall Study of Formulaic Expressions. c, 24-30.

Klancar - Developing Speaking Skills in the Young Learners Classroom (TESL_TEFL). (n.d.).

Kurniasih, E. (2011). Teaching the Four Language Skills in Primary EFL Classroom: Some Considerations. 1(1), 70-81.

Malihah, N. (n.d.). The Effectiveness of Speaking Instruction through TaskBased Language Teaching. 3(1), 85101.

Nurjanah, R. L. (2020). Self-Regulated Learning Strategy Instructions in Reading Comprehension Skill Learning During Outbreak Era. 5(2), 191-201.

Overdijk, M. (2009). Appropriation of Technology for Collaboration from Mastery to Utilisation (Issue

|ELT-Lectura: Studies and Perspectives in English Language Teaching

Copyright@ 2021 Ratih Laily Nurjanah, Deswandito Dwi Saptanto, Maya Kurnia Dewi 
September).

Pakula, H. (2019). Teaching speaking. November.

https://doi.org/10.17011/apples/urn.20

1903011691

Piña, A. A. (n.d.). Instructional Design Standards for Distance Learning Edited by Sullivan University.

Salisu, A., \& Ransom, E. N. (2014). The role of modeling towards impacting quality education. 32, 54-61. https://doi.org/10.18052/www.scipress .com/ILSHS.32.54

Sutarsyah, C. (2017). An Analysis of Student's Speaking Anxiety and its Effect on Speaking Performance. 1(2), 143-152.

Wandler, J. B., \& Imbriale, W. J. (2017). Promoting undergraduate student selfregulation in online learning environments. Online Learning Journal, 21(2). https://doi.org/10.24059/olj.v21i2.881

Widiati, U. (n.d.). THE TEACHING OF EFL SPEAKING IN THE INDONESIAN CONTEXT: THE STATE OF THE ART. 2002, 269-292.

Yanti, S., Sinuraya, B., Anshari, K., \& Hadi, W. (n.d.). The Development of Teaching Materials Poetry Reading Based on Contextual Approaches in 8 th Grade Students of Junior High School 1 Pancur Batu. 433-446. 